\title{
水面浮上性粒状製剂技術の開発
}

\author{
関口幹夫, 高橋 嶡, 栘井昭夫, 小島敏克 \\ 日本化薬株式会社化学品事業本部農薬事業部上尾研究所
}

\section{Formulation Technique of Granules Resurfacing after Submerged Application}

\author{
Mikio Sekiguchi, Iwao Takahashi, Akio Masui \\ and Toshikatsu Kojıma \\ Ageo Research Laboratory, Nippon Kayaku Co., Ltd., \\ Koshikiya, Ageo 362, Japan
}

\begin{abstract}
This formulation study is conducted for unique granules with a pesticide delivery system to use the active ingredient efficiently in the paddy field. When the granules are scattered, they sink down on the bottom soil at first. Then the granules resurface and diffuse the active ingredient on the water surface. As the solid materials of the granules dissolve completely into the water, finally the concentrated active ingredient is left there. This resurfacing behavior of particle is caused by the binding agent transformed to a hydrosol with water and to hold air existing in the particle as well as by reduction of the particle weight due to dissolution of the solid material in water. In case of insecticide cycloprothrin granules of this type, about $75 \%$ of cycloprothrin was distributed on water surface and in water 2 hours after application, while in case of a ordinary granule formulation only about $20 \%$ of the active ingredient was distributed there. This type of granules containing insecticidal active ingredients showed for higher efficacy than the ordinary granules against several kinds of injurious paddy insects. Cycloprothrin $2 \%$ granules (Cyclosal $2 \mathrm{UG} \otimes$ ) was completed by this granular formulation technique as a result of selection of raw materials, establishment of manufacturing process, product quality investigation, and others.
\end{abstract}

\section{緒言}

粒剂が水稲害虫防除に使用されたのは 1960 年以降で, 1961 年に BHC 粒剂が生産されるようになって以来, 研 究と並行して着々と普及に移され，ニカメイチュウのほ かウンカ類, 、モグリバェ類, イネクビホソハムシ（通称 イネドロオイムシ）等多くの害虫に卓効を示してきた. その後, $\mathrm{BHC}$ 粒剤が生産中止となるに及んでダイア ジノン粒剤等が多く使用され， BHC で望めなかったツ マグロヨコバイの防除も可能になり, 水稲害虫以外にも イグサシンムシガや水稲害虫とコガタアカイエカの併殺 も可能となった.

粒剂の使用については, 特殊な器具を使用しないでも
簡単に手撒きできること, 粉剤や液剂散布のよらな飛散 による周辺への影響が少ないこと，効果面でも残効性に 優れていること等から急速に普及し, 田植機の普及につ れて育苗箱施薬の基礎技術にもなった.

粒剂の殺虫機構は，水田に落下した薬剤がイネの根か ら吸収されて茎葉部に移行したり，水中に溶解している 薬剤が毛細管現象で葉鞘間隙を上昇する浸透移行効果や 水面から蒸散する有効成分のガスによる直接的またはガ スのイネ体付着による間接的なガス効果とされている. したがって，粒剤として応用可能な有効成分としては力 価に比較して水溶性が比較的高いもの，蒸散性が高いも のがあげられる (Table 1). 一方, 水溶性の低い活性成 分の水稲害虫に適応する製剂として油剤があげられる. 
Table 1 Properties of insecticides used for submerged application.

\begin{tabular}{lrll}
\hline Insecticide & $\begin{array}{c}\text { Water } \\
\text { solubility } \\
(\mathrm{ppm})\end{array}$ & Systemic & $\begin{array}{l}\text { Vapour } \\
\text { action }\end{array}$ \\
\hline Cartap & $>10,000$ & High & Low \\
Thiosyclam & $>10,000$ & High & Low \\
PHC & 2000 & High & Medium \\
MPP & 55 & Medium & Low \\
Ethylthiometon & 25 & Medium & Medium \\
Diazinon & 40 & Medium & High \\
Buprofezin & 0.9 & Medium & Low \\
\hline Cycloprothrin & 0.09 & Low & Low \\
\hline
\end{tabular}

江戸時代にウンカ類の防除に使用された動植物油の注油 駆除法が明治時代に入り石油に変わるとともに, 1904 年 に除虫菊浸出石油が実用化され農薬の水面施用の葶矢と なった.

1928年にはこの除虫菊浸出石油がイネゾウムシの防除 に有効なことが確認され，戦後は除虫菊に代わり $\mathrm{BHC}$, ダイアジノン，イソキサチオン等の油剤化が試みられて きた．乙かし，油剤は施用方法や薬害の面で問題もあり 水面施用の主体は粒剂となった．本開発研究の水面浮上 性粒剂は粒剂と油剤の長所を活かした製剂を目的とし た.

1976年に日本に侵入したイネミズゾウムシに対して既 存の各種水稲害虫防除剤の適応が試みられたが，イネミ ズゾウムシに対する殺虫活性が低いこと，本虫が水上． 水中生活を営んでいることなどからこれを有効に防除す る新規薬剤が求められていた.

シクロプロトリンはイネミズゾウムシに対して高い活 性を示すが，扣もに接触作用であり，浸透移行作用やガ ス作用を期待できなかったため，イネミズゾウムシの行 動に合わせた pesticide derivery system を考光, 有効成 分を水面に効率よく展開させる製剤を開発した，さらに イネクビホソハムシのよらに水中では行動しないがイネ 体上での行動のなかで少しでも薬剤に接触することによ り脚部が麻痺し, 茎葉から水面に落下し, 水面に存在す る高濃度の有効成分に触れ, 死亡に至ることが判明し, このような茎葉部の害虫まで適用が広がることがわかっ た。

本粒剈の開発にあたっては，過去，例を見ない製剤で あるゆ元に効力, 薬害はもとより, 生産性, 散布性, 保 存中の物理的・化学的安定性なぞを慎重に検討し, 本水 面浮上性粒状製剤を完成した。

\section{開 発の 経 䋹}

薬剤を水面施用した場合にいかに有効成分を効率的に 防除効果に結びつけるかの試みとして浮遊性粒剤の研究 が従来から行なわれており，特許公報 ${ }^{1210)}$ や特許公開公 報11,12)に多くの技術が開示されている。 それは，水中に 沈降する一般の粒剤は土壤表面に定着するため有効成分 が土壤に吸着されやすいのに比較して浮遊粒剤は土壤に 粒子が接触しないため, 水中や水面の有効成分量が多く なり，茎葉からの稲体への浸透移行性やガス作用を高め ることができるといら発想によるものである．著者らは 特許情報や独自の技術により浮遊性粒剂の研究を長年実 施してきたが，試作したそれぞれの浮遊性粒剂には共通 した問題点があり，実用化に至らなかった。問題点とし ては散布後水面に浮遊しているとき風の影響を受けや すく，水田に有効成分を均一に分布させることが困難で あること，粒剤から有効成分が放出されにくいこと，製 剤価格が高いこと等であった。

本水面浮上性粒剂の開発研究は水面施用剂之は関係の ない硼砂粒状物の製造研究が発端になった．著者らは過 去, ダイアジノンやプロパフォスなどのコーティング粒 剤の開発に関与してきたことから，この技術を活かして 幅広い粒度分布の硼酸ナトリウムを一定の粒度のビーズ 状硼砂粒状物に加工にする研究の機会を得た．原料の硼 酸ナトリウムと目標の対照品の粒度分布があまりにも異 なるため無理難題と思いつつも，鋭意研究した結果，注 ぼ当初の目標を満足する粒状物ができた。この硼砂粒状 物を水中に入れると一旦沈下してやがて浮上し，風の影 響を受けにくい状態で水面に浮遊し，最終的に水に全量 溶解することが判明した．このような特性を持つ粒状物 はこれまで研究してきた浮遊粒剂の欠点を解消する粒剂 の基剤となりらるのではないかと考えた．実際に殺虫有 効成分を保持させて殺虫力を試験したところ，従来の粒 剤（沈降性）や浮遊性粒剂よりも優れた殺虫効果を発揮 したため，さらに経済的な製造方法や品質上の問題点な ぞを検討して完成に至った。

本開発研究は農林水産省の主催する「農薬資材費低減 化技術確立事業」(1988 年度) に扮いてダイアジノンで 取り組み，その後シクロプロトリンに応用し，より低薬 量にて優れた効果を発揮する水面浮上性粒剂「シクロサ ールU粒剤 2 」を開発し，1987 年より上市に至った。ま た，特許は 1988 年に公告13)となった。

\section{浮遊性粒剤（フローティング粒剤）の研究・問題点}

多孔性粒状担体として軽石，バーミキュライト，焼成 
Table 2 Active ingredient released from granules to water.

\begin{tabular}{|c|c|c|c|c|c|}
\hline \multirow{3}{*}{ Basic granules } & \multirow{3}{*}{$\begin{array}{l}\text { State } \\
\text { in } \\
\text { water }\end{array}$} & \multicolumn{4}{|c|}{ Released active ingredient } \\
\hline & & \multicolumn{2}{|c|}{$\left.1 \mathrm{DAT}^{\mathrm{a}}\right)$} & \multicolumn{2}{|c|}{$3 \mathrm{DAT}$} \\
\hline & & $\begin{array}{l}\text { In water } \\
(\mathrm{ppm})\end{array}$ & $\begin{array}{l}\text { On water } \\
(\mu \mathrm{g})\end{array}$ & $\begin{array}{l}\text { In water } \\
(\mathrm{ppm})\end{array}$ & $\begin{array}{c}\text { On water } \\
(\mu \mathrm{g})\end{array}$ \\
\hline \multicolumn{6}{|l|}{ For diazinon $5 \% \mathrm{G}^{\mathrm{b}}$ ) } \\
\hline $\begin{array}{l}\text { Vermiculite }(75 \%) \\
\text { Solid paraffin }(25 \%)\end{array}$ & Float & 2.28 & 1.05 & 3.56 & 0.78 \\
\hline $\begin{array}{l}\text { Polyethylene polyvinyl } \\
\text { acetate copolymer }\end{array}$ & Float & 0.36 & 0.49 & 0.73 & 0.21 \\
\hline Diazinon $5 \%$ G (on market) & Sink & 5.81 & 1.94 & 10.48 & 2.57 \\
\hline \multicolumn{6}{|l|}{ For cycloprothrin $2 \% \mathrm{G}$} \\
\hline $\begin{array}{l}\text { Vermiculite }(75 \%) \\
\text { Solid paraffin }(25 \%)\end{array}$ & Float & 0.001 & 0.15 & $<0.001$ & $<0.001$ \\
\hline $\begin{array}{l}\text { Polyethylene polyvinyl } \\
\text { acetate copolymer }\end{array}$ & Float & 0.001 & 0.11 & $<0.001$ & $<0.001$ \\
\hline Pumice $(96 \%)$, Surfactant $(4 \%)$ & Sink & 0.092 & 9.5 & 0.006 & 8.2 \\
\hline
\end{tabular}

a) Days after treatment. b) Granules.

パーライト，シラスバルーンを使用し，撥水剤としてヌ カワックス, 固形パラフィン，シリコン系执よびフッ素 系化合物を使用した浮遊性粒状基剤にダイアジノン $5 \%$ またはシクロプロトリン $2 \%$ を含む浮遊性粒剤, 粒状ポ リエチレンーポリ䣷酸ビニル共重合体にダイアジノン 5 \%またはシクロプロトリン $2 \%$ を含浸させた浮遊性プラ スチックス製剤を作成し，有効成分の水中での挙動を検 討した．なお，シクロプロトリンの工業品は高粘度のた め不揮発性溶剂で $35 \%$ に希釈して使用した. その一部 を Table 2 に示す. $12 \mathrm{mg}$ の浮遊性粒剂を水 $200 \mathrm{ml}$ 入 った直径 $10 \mathrm{~cm}$ の腰高シャーレに入れ，1 日後，3日後 に水面（直径 $10 \mathrm{~cm}$ の濾紙を水面に浮かべて引き上げ, 濾紙への付着量を測定）および水中の有効成分量を分析 した結果，浮遊性粒剤では，有効成分が撥水剂や鉱物質 担体，またはプラスチックスのなかに取り込まれた状態 になり，水への放出が少なくなったため，むしろ沈降性 粒剂よりも有効成分の放出は抑制されていた。また，浮 遊している粒の上部が水面上に出ているためわずかの風 でも風下に吹き流されるといら久点もあった.

\section{硼砂粒状物の製造研究}

水面浮上性粒剤の開発の発端になった硼砂粒状物の製 造研究について概要を述べる.

原料となる 5 水塩の硼酸ナトリウムは Fig. 1 のよら に 12〜35メッシュ (0.4〜1.4 mm) に50\% 強が, 35 メ ッシュ穊下に $50 \%$ 弱が分布する幅広い粒度分布を有し， 目的とする粒状物は対照品の 12 メッシュから 35 メッシ

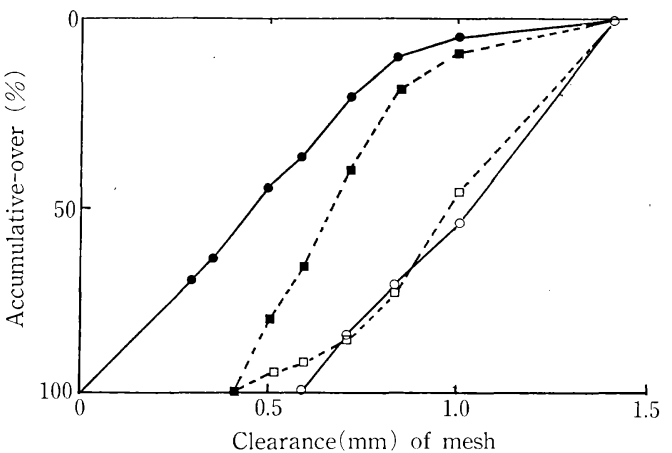

Fig. 1 Particle size distribution of borax.

$\bigcirc$, Manufactured granules; $\square$, Standard granules;

- Raw borax; $\mathbf{\square}$. Sieved granules (12-35 mesh) of raw borax.

ュに95\% 以上を有する硬い球形のもので, 水中で溶解 する必要があり, しかもこの原料を余すことなく使用し たいといら条件付きであった，このような条件から製造 方法として 35 メッュュ穊上品を粉砕して粉末にし，35 メッシュ穊上品の粒核に被覆する方法を考えたが，粒核 に対してほぼ同量の粉末を硬く被覆しなくてはならない ため, 結合剤の選択が最も重要なポイントであった. 結 合剂としては硼酸ナトリウムが速やかに水に溶ける必要 があることから水溶性のものを検討した．具体的にはリ グニンスルフォン酸ナトリウム, ポリビニルアルュール, ゼラチン，水溶性デンプン，デキストリン，ポリアクリ ル酸ナトリウム, ケイ酸ナトリウム等を数段階の濃度で 


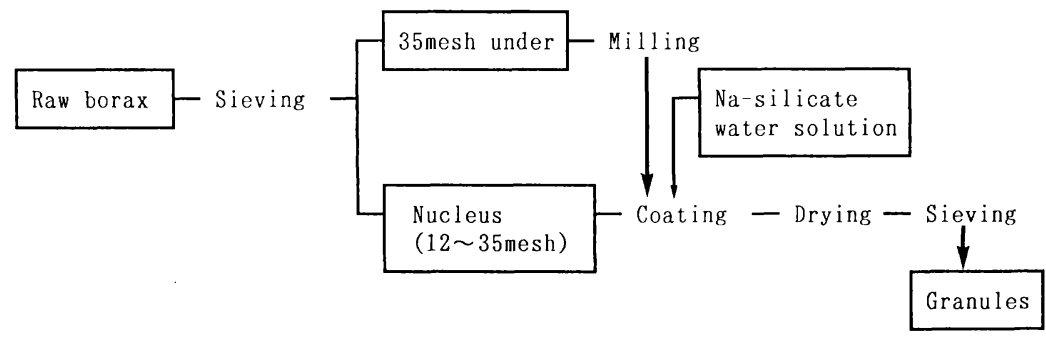

Fig. 2 Manufacturing process of borax granules.

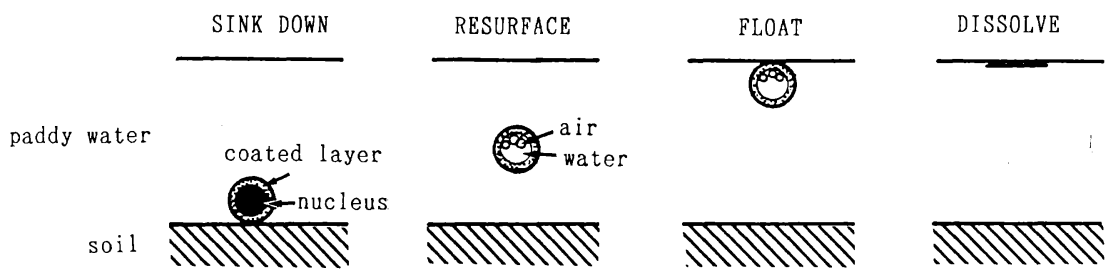

Fig. 3 Behavior of manufactured borax granules in paddy.

水に希釈して使用した．その結果，合成あるいは天然の 有機物では目標に程遠く，無機物のケイ酸ナトリウムの みが目的の条件を満たし，ケイ酸ナトりウム JIS 1 号を 同量の水で希釈して使用するのが最適であることが判明 し, Fig. 2 のフローで製造した.

この䂽砂粒状物は水中に入れると一旦沈降し，その一 部が数分以内に水面に浮上し, 半溶解状態で上部が水面 に接して浮遊しながらやがて水に溶解してしまうことを 発見した. この粒状物に殺虫活性成分シクロプロトリン $2 \%$ を溶剂とともに被覆し，イネミズン゙ウムシに対す る殺虫効力扣よび有効成分の水面展開量を調べたとこ ろ, 従来の粒剂に比較してかなり殺虫効力が高く，水面 展開量も多いことが判明した．水面浮上のメカニズムは Fig. 3 に示す．まず，粒状物が水中に沈下すると粒核 の硼酸ナトリウムが水中に溶出し, 被覆層のケイ酸ナト リウムが水で高粘度のコロイド状になって被覆層中の硼 酸ナトリウムとともにバルーンを形成する．粒状物中に 少量存在する空気がこのバルーン内に残り，浮上の原動 カとなる。 また，水面に浮上したバルーンは浮遊しなが ら時間とともに溶解し，注とんどなくなってしまう。こ のような特性を有する粒剤の条件としては，固体の担体 が水より重く水溶性であり, 結合剂が水を吸収して高粘 度になり，粒子内に存在する空気を捕捉できることが必 要であることがわかった.

\section{水面浮上性粒剤の開発研究}

上記の嗍砂粒状物は水面施用の粒剂基剤として優れた
効果を発揮するが，粒状物の一部しか浮上しないこと， $\mathrm{pH}$ が高いこと，製剤価格が高くなるなど実用的には改 良の余地があるため, 浮上率が高く, 十分に経済的に製 造でき，さらに $\mathrm{pH}$ 領域が中性に近い水面浮上性粒剤の 開発研究を行なった. 硼砂粒状物の製造はコーティング 法で行なったが，検討する種々の原材料として粉末のほ うが入手しやすいことから加水混練押し出し造粒法によ り検討した.

\section{1. 粉末担体の選択}

必要条件として，水溶性が高く，速やかに水に溶解す ること，造粒性に問題がないこと，経済的に製造できる こと，空気中の水分の影響を受けにくいことなどがあげ られる. Table 3 はこれらについて検討したおもな結果 である．塩化ナトリウム（工業用）は吸湿して潮解しや すく, 硫酸ナトリウムは加水混練時に固結して造粒しに

Table 3 Properties of tested carrier for RSG. ${ }^{a}$ )

\begin{tabular}{llll}
\hline $\begin{array}{c}\text { Carrier } \\
\text { (technical grade) }\end{array}$ & $\begin{array}{c}\text { Possibility } \\
\text { of } \\
\text { granula- } \\
\text { tion }\end{array}$ & $\begin{array}{c}\text { Solubility } \\
\text { in water }\end{array}$ & $\begin{array}{c}\text { Deliques- } \\
\text { cency }\end{array}$ \\
\hline Sodium chloride & High & High & Medium \\
Potassium chloride & High & High & Low \\
Calcium chloride & Low & High & High \\
Sodium sulfate & Low & Medium & Low \\
Potassium sulfate & Medium & Medium & Low \\
Ammonium sulfate & Low & High & High
\end{tabular}

a) Resurfacing granules. 
くかった. 硫酸カリウムは水中での溶解が遅すぎて浮上 しにくく，また，塩化カルシウムと硫酸アンモニウムは 吸湿性と造粒性の面であまり適当ではなかった，塩化カ リウムのみが経済性, $\mathrm{pH}$ も含めて比較的どの条件も満 たし粉末担体として使用できると判断した.ただし，一 般的に肥料として使用されるグレードのものは吸湿潮解 性を示し適切ではなかった。 なお, 試験項目の潮解性は $30^{\circ} \mathrm{C}$ 湿度 $90 \%$ の条件下に粉末のまま置き, 外観变化と 重量変化を調査し, 水溶性は粉末の水中での溶解状態を 観察した. また，造粒性は各粉末をアラビアガム $1 \%$ そ 混合し，加水混練して造粒機で押し出し，その状海を観 察した.

\section{2. 結合剤の選択}

矹砂粒状物の研究に和ける知見に基ついて考えると， 水面浮上性粒剂の結合剂には担体粉末粒子間の結合と, 粒状物内に存在する空気を水中で捕捉する二つの機能を 必要とし，また, 製造の加水混練時には水に溶解して混練 物に可塑性を付与し，造粒しやすくすること，粒状に成 形後乾燥することによって結合力を発揮して製品の保存 中の輸送中抢よび散布時の粉化を防止することを必要と する. 粒状物に必要な特性としては水中に沈んだ粒子に 浮上性を与えること，つまり，水中で粘椆な状態を保ら， すぐには完全に溶解しないことがあげられる. Table 4 は塩化カリウム粉末にそれぞれの結合剂を混合して粒状 物を製造し，造粒性，浮上性を検討した結果の一部であ るが，そのなかではアルギン酸ナトリウムが良好であ った. しかし，アルギン酸ナトリウムで製造した粒状物 は保存中に変化し, 浮上性が劣化したため,これら結合 剤の組合せによる適性を検討したところポリアクリル酸 ナトリウム（高重合品）とキサンタンガムの組合せがす べての項目を満足させ，水面浮上性粒郕にとって最適で あった.この粒状物は被覆層にのみ結合剂が存在する球 形粒子の硯砂粒状物と異なって, 粒子中にほぼ均一に結 合剂が存在する円柱状粒子であり，水中で多数の小さな 気泡を内抱するため（Fig．4）水面浮上性は非常に良好 であった.この理由としては結合剤がマトリックス状に なり粒子中の空気を効率よく捕捉できるためと考えた。 水面では嗍砂粒状物の場合と同様に水面に接するように 水面下に存在するため風の影響を受恼にくかった.

\section{3. 水面展開性の付与}

本粒状基剤に保持させる有効成分は，水面に展開させ るために油状液体にして拉く必要があり，有効成分が固 体や高粘性液体の場合には適切な溶剤と混合して粘度を 下げる必要がある。また, 界面活性荗を添加することに より，水面展開性をさらに良好にすることも可能であっ
Table 4 Properties of binding agents.

\begin{tabular}{|c|c|c|}
\hline Binding agent & $\begin{array}{l}\text { Possibility } \\
\text { of } \\
\text { granulation }\end{array}$ & $\begin{array}{l}\text { Resur- } \\
\text { facing }\end{array}$ \\
\hline Water-soluble starch & High & Low \\
\hline $\mathrm{Na}$-alginate & High & High \\
\hline Xanthan gum & High & High \\
\hline $\begin{array}{l}\text { Na-Polyacrilate } \\
\text { (high polymer) }\end{array}$ & Medium & Medium \\
\hline $\begin{array}{l}\text { Na-carboxymethyl } \\
\text { cellulose }\end{array}$ & Medium & Medium \\
\hline Polyvinylalcohol & Medium & Low \\
\hline Gum arabi & High & Medium \\
\hline $\begin{array}{l}\text { Xanthan gum } \\
\text { Na-Polyacrilate(high }\end{array}$ & $\begin{array}{l}\text { High } \\
\text { ner) }\end{array}$ & High \\
\hline
\end{tabular}

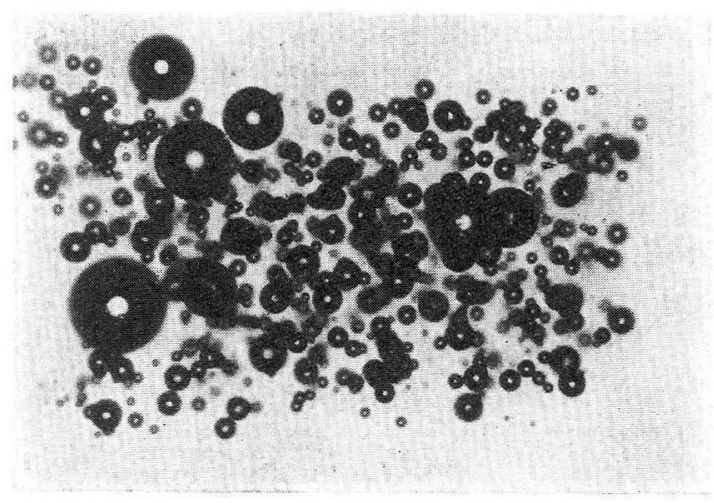

Fig. 4 Floating state of RSG in water.

Picture of coloidal binder holding air bubbles after solid carrier dissolving. $\times 40$.

た. 油状液体に使用する溶剂としては有効成分の溶解能 力があること以外に比重が 1 以下であること，低揮発性 で引火性がないことが重要であり，また，作物に対する 薬害についても十分に検討する必要がある. シクロプロ トリン粒剤では, 溶剤としてはプラスチックの可塑剤と して使用されるフタル酸ジイソデシル等, 界面活性剤と してはエチレンオキサイドとプロピレンオキサイドの共 重合物等が適当であった.

\section{4. 製造方法}

Fig. 5 のよらな製造フローで原材料を加水混練し, 造 粒機でスクリーンから押し出し，造粒する．有効成分は あらかじめ水面に展開しやすい液状にし，最初の混合の ときに加えるか, あるいは乾燥後の粒状物に吸着させれ ばよいが，有効成分が乾燥時の熱に影響をうける場合 や，造粒時の口スを考えると，吸着させる方法が沉用性 


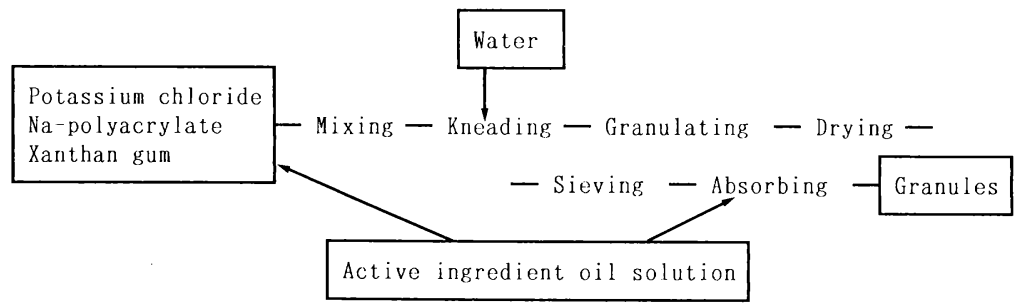

Fig. 5 Manufacturing process of RSG.

がある．製造にあたっては原材料に無機塩を使用してい るため金属部分が錆びやすく，問題になる部分はステン レス等の錆に強い材質にした。 また，原材料には無機塩の なかでも吸湿性の比較的少ないものを選択したが，水分 量によっては積久重祆保存した場合に積久荷の重量圧 がかかり，加圧が長期間に及ぶと固結する心配があり， 製造時の水分管理を十分に行ならことや，包装材料には 透湿性のないものを使用すること等の配慮が必要であ った。な拈，塩化カリウムを使用した場合，粒剤中の水 分は約 $0.5 \%$ 以下に管理すれば十分であった。

\section{水面浮上性粒刘の殺虫効力試験}

上記の水面浮上性粒剤をダイアジノンとシクロプロト リンに応用した殺虫効力試験の結果を記載する.

\section{1. ダイアジノン水面浮上性粒㓮}

ウンカ・ヨコバイ類に対するダイアジノン粒剤の水面 施用の効果は，水田に施用された粒剂の有効成分が一部 は水中に溶解してイネ体に吸収され，茎葉に移行してウ ンカ・ヨコバイ類の吸汁による殺虫作用，一部は蒸散し た有効成分のガスによる殺虫作用とされている ${ }^{14,15)}$ ，と ころが，沈降性の従来の粒剤では粒子が土壤表面に沈下 して有効成分の一部が土壌に吸着するため, 水面・水中 の濃度をさらに高めてこれらの作用を効率的に発揮させ

Table 5 Efficacy of diazinon 5\% RSG against smaller brown planthopper.

\begin{tabular}{|c|c|c|c|}
\hline \multirow[t]{2}{*}{ Treatment } & \multirow{2}{*}{$\begin{array}{l}\text { Dosage } \\
(\mathrm{kg} / \\
10 \mathrm{a})\end{array}$} & \multicolumn{2}{|c|}{$\begin{array}{l}\text { Mortality of hop- } \\
\text { pers at } 24 \mathrm{HAR}^{\mathrm{a}} \text { ) }\end{array}$} \\
\hline & & $0 \mathrm{DAT}$ & $1 \mathrm{DAT}$ \\
\hline $5 \% \mathrm{RSG}$ & $\begin{array}{l}2 \\
4\end{array}$ & $\begin{array}{l}92.5 \\
90.0\end{array}$ & $\begin{array}{rl}92 & 5 \\
100 & 0\end{array}$ \\
\hline $5 \%$ G (on market) & $\begin{array}{l}2 \\
4\end{array}$ & $\begin{array}{l}400 \\
47.5\end{array}$ & $\begin{array}{l}67.5 \\
725\end{array}$ \\
\hline Untreatment & - & 2.5 & 00 \\
\hline
\end{tabular}

Figures in column mean averages of 2 replications.

a) Hours after releasing of hoppers.
るため, ダイアジノン $5 \%$ の水面浮上性粒剤で試験し た ${ }^{16)}$ ．その結果，Table 5 のガラス円筒をかぶせたポッ 卜試験で示すように面積当りの有効成分量が $1 / 2$ にもか かわらず，市販ダイアジノン粒剂 5 と同等以上の効果を 発揮し, また，外部公共試験機関の固場試験の結果でも 同様の結果が確認された。

\section{2. シクロプロトリン水面浮上性粒郕}

シクロプロトリンは水溶解度が $90 \mathrm{ppb}$ ときわめて低 く，蒸散性もほとんどないことから従来の沈降性の粒㓮 では水面施用剂として十分な殺虫効果を期待できないこ とから，水面浮上性粒剂を検討した. シクロプロトリン の水面浮上性粒剂はイネミズゾウムシを対象に当初 $3 \%$ の粒剂で試験し，高い殺虫効果を示した（Table 6)。そ の後, $2 \%$ 粒剤の $1 \mathrm{~kg} / 10 \mathrm{a}$ 散布でも従来の沈降性粒剂 の $2 \mathrm{~kg} / 10 \mathrm{a}$ 散布, 市販の対照薬剂(MPP • BPMC 粒剂) を凌ぐ高い効果を示した (Table 7)。 また，水田中のシ クロプロトリンの各部への分布量を測定した結果，水面 浮上性粒剂は散布 2 時間後に散布した量の約 $75 \%$ が水 面拈よび水中に分布し，徐々に土壤へ移行していった が，沈降性粒剤では約 $20 \%$ が分布するにすぎなかった

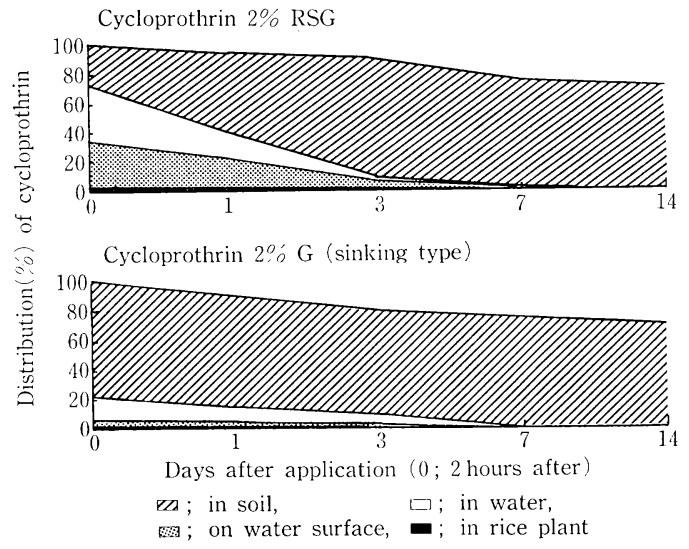

Fig. 6 Distribution of cycloprothrin after submerged granule application. 
(Fig. 6)。本剤は 1984 年より本格的に日本植物防疫協 会の委託試験に供試され，イネミズゾウムシに対して上 記対照薬剂と同等ないしそれ以上の優れた防除効果が実 証された。

当初, イネクビホソハムシはイネミズゾウムシ成虫の ように水中では行動しないで茎葉部に生息するため, シ クロプロトリン粒剤では防除がきわめて困難であららと 推測していたが，イネミズゾウムシ防除のため水面浮上 性粒剂を散布することにより同時期に発生するイネクビ ホソハムシ成・幼虫にも高い防除効果を示す事例が多く
報告された．この情報をもとに，水田を仕切り（1 mx $1 \mathrm{~m}), \quad 1.5 \mathrm{~kg} / 10 \mathrm{a}$ 相当量のシクロプロトリン水面浮上 性粒剂を水面施用した後,イネクビホソハムシ成虫 40 頭 を放虫し，その後の成虫，卵塊，幼虫数を調查したとこ ろ高い殺成虫効果を示し，幼虫も十分に防除できること が確認された (Table 8).

${ }^{14} \mathrm{C}$ でラベルしたシクロプロトリン $2 \%$ の水面浮上性 粒剤の $1.5 \mathrm{~kg} / 10 \mathrm{a}$ 相当量を散布した後のイネ株部位別 の分析結果では水面上 $15 \mathrm{~mm}$ までの葉䩗には 2 90 ppm のシクロプロトリンが検出されたが，それより上の

Table 6 Rice water weevil control with cycloprothrin 3\% RSG.

\begin{tabular}{|c|c|c|c|c|c|}
\hline \multirow{2}{*}{ Treatment } & \multirow{2}{*}{$\begin{array}{c}\text { Dosage } \\
(\mathrm{kg} / 10 \mathrm{a})\end{array}$} & \multicolumn{3}{|c|}{ No. of weevils per 100 hills } & \multirow{2}{*}{$\begin{array}{l}\text { No. of } \\
\text { larvae } \\
\text { per hill }\end{array}$} \\
\hline & & $0 \mathrm{DAT}$ & $1 \mathrm{DAT}$ & $6 \mathrm{DAT}$ & \\
\hline Cycloprothrin 3\% RSG & $\begin{array}{l}1 \\
2 \\
3\end{array}$ & $\begin{array}{r}110 \\
123 \\
52\end{array}$ & $\begin{array}{r}12 \\
1.5 \\
1.5\end{array}$ & $\begin{array}{l}33 \\
16 \\
18\end{array}$ & $\begin{array}{r}21.8 \\
14.5 \\
7.3\end{array}$ \\
\hline Cycloprothrin 3\% G & 3 & 71 & 4 & 36 & 14.5 \\
\hline Cycloprothrin 1\% Dust & 3 & 115 & 2 & 6.5 & 15.2 \\
\hline $\mathrm{BPMC} \cdot \mathrm{PHC} \mathrm{G}$ & 3 & 170 & 9.5 & 23 & 28 \\
\hline Untreatment & - & 109 & 94 & 121 & 42.1 \\
\hline
\end{tabular}

Table 7 Rice water weevil control with cycloprothrin $2 \%$ RSG.

\begin{tabular}{|c|c|c|c|c|c|c|}
\hline \multirow{2}{*}{ Treatment } & \multirow{2}{*}{$\begin{array}{c}\text { Dosage } \\
(\mathrm{kg} / 10 \mathrm{a})\end{array}$} & \multicolumn{4}{|c|}{ No. of weevils per 100 hills } & \multirow{2}{*}{$\begin{array}{l}\text { No. of } \\
\text { larvae } \\
\text { per hill }\end{array}$} \\
\hline & & $-1 \mathrm{DAT}$ & $1 \mathrm{DAT}$ & $3 \mathrm{DAT}$ & $6 \mathrm{DAT}$ & \\
\hline Cycloprothrin $2 \%$ RSG & $\begin{array}{l}1 \\
2 \\
4\end{array}$ & $\begin{array}{r}102 \\
92 \\
151\end{array}$ & $\begin{array}{l}1 \\
0 \\
3\end{array}$ & $\begin{array}{l}3 \\
1 \\
0\end{array}$ & $\begin{array}{l}1 \\
0 \\
1\end{array}$ & $\begin{array}{l}4.4 \\
2.3 \\
0.4\end{array}$ \\
\hline Cycloprothrin $2 \% \mathrm{G}$ & 2 & 67 & 7 & 23 & 32 & 3.9 \\
\hline $\mathrm{BPMC} \cdot \mathrm{PHC} \mathrm{G}$ & 4 & 58 & 7 & 0 & 13 & 5.0 \\
\hline Untreatment & - & 85 & 140 & 142 & 170 & 16.8 \\
\hline
\end{tabular}

Table 8 Rice beetle control with cycloprothrin 2\% RSG.

\begin{tabular}{llcccc}
\hline \multirow{2}{*}{ Treatment } & & \multicolumn{3}{c}{ No. of adults, egg masses and larvae } \\
\cline { 3 - 5 } & & -1 DAT & 1 DAT & 7 DAT & 10 DAT \\
\hline \multirow{2}{*}{ Cycloprothrin 2\% RSG $(2 \mathrm{~kg} / 10 \mathrm{a})$} & Adults & 40 & 0 & 0 & 5 \\
& Egg mass & 2 & $\mathrm{NC}^{\mathrm{a})}$ & 6 & 1 \\
& Larvae & 2 & 0 & 0 & 5 \\
Untreatment & Adults & 40 & 20 & 0 & 0 \\
& Egg mass & 1 & NC & 26 & 9 \\
& Larvae & 1 & 0 & 0 & 52 \\
\hline
\end{tabular}

In $1 \mathrm{~m} \times 1 \mathrm{~m}$ of rice field devided with plastic board, 40 rice beetles were released before treatment.

a) Not conducted. 
葉身からはイネクビホソハムシ成虫にまったく影響のな い0.4 ppm 以下しか検出されず (Table 9), 葉身からの 接触・経口による死亡は考えられなかった，ところが， イネクビホソハムシ成虫には茥葉間移動をする場合など 頻繁に葉鞘を伝って水面近くに降下し, 再度上昇する行 動がみられ，致死量以下の濃度ではあるが水面近くの葉 鞘部の有効成分と接触することにより脚部に異常をおこ し，有効成分の高い水面に落下し，死に至ることが観察 された。この事実は次の室内試験でも確認された。 また 木枠 $(100 \mathrm{~cm} \times 60 \mathrm{~cm})$ に水田土壤执よび水を入れ，イネ 稚苗を $15 \mathrm{~cm}$ 間隔に移植し，シクロプロトリン $2 \%$ の水 面浮上性粒剂を $1.5 \mathrm{~kg} / 10 \mathrm{a}$ 処理した区と，対照として 水面にサラダオイルのみを展開させた区に防虫網をから゙ せ，成虫 20 頭を放飼した結果は，Fig. 7 のよらに浮上 性粒剂区では 72 時間ですべての成虫が落下死亡し, 固 場における効果が再確認されたが，サラダオイル区では 半数以上が生息していた ${ }^{17,18)}$.

また，活性成分が水面に展開するエトフェンプロック

Table 9 Concentrations of active ingredient on rice sheathes in cycloprothrin $2 \%$ RSG application.

\begin{tabular}{crrr}
\hline $\begin{array}{c}\text { Parts of sheath } \\
\text { from water } \\
(\mathrm{mm})\end{array}$ & \multicolumn{3}{c}{ Concentration in ppm } \\
\cline { 2 - 4 } & 1 DAT & 3 DAT & 5 DAT \\
\hline $0-5$ & 61.1 & 30.6 & 88.8 \\
$5-15$ & 50.8 & 2.7 & 2.6 \\
$15-25$ & 0.4 & 0.2 & 0.2 \\
$25-35$ & 0.2 & 0.3 & 0.1 \\
$35-95$ & 0.1 & 0.1 & 0.1 \\
\hline
\end{tabular}

Figures in column mean averages of 3 replications.

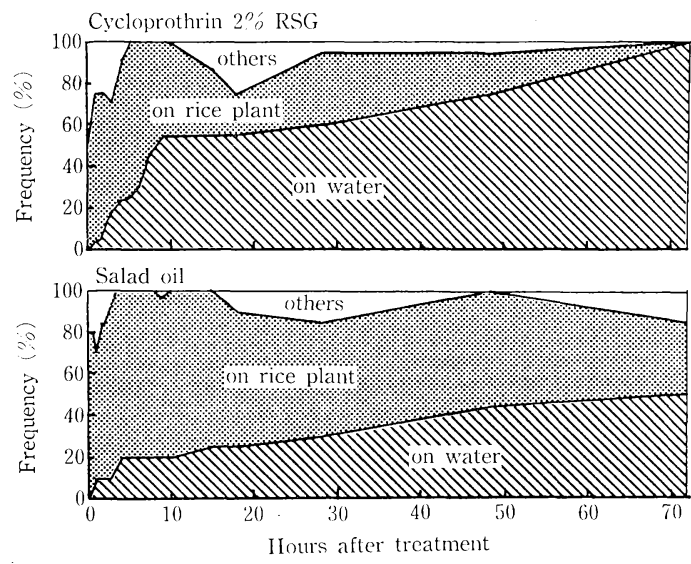

Fig. 7 Knock-down percentages of rice beetle on water.
ス粒剂の試験では波風により水面の薬剤がイネのかなり 上部まで付着したり，水面に垂れたイネ葉にも付着して イネクビホソハムシの成虫に作用するといら報告 ${ }^{19)}$ む あり, シクロプロトリン水面浮上性粒剤の場合にも同様 の効果があると考えられる。

\section{散布機適合性の検討}

従来の粒剂と原材料が異なるため，通常の散布機で支 障なく散布できるかシクロプロトリン水面浮上性粒剤を 使用して試験したところ，1.5 2.0 kg/10 a が通常の粒 剂の $3.0 \mathrm{~kg} / 10 \mathrm{a}$ の吐出量に相当し (Fig. 8), 同じシャ ッター開度で試験した散布機からの距離別落下粒子量の 分布も対照の粒剂と類似し (Fig. 9), 通常の粒剤の 3.0 $\mathrm{kg} / 10 \mathrm{a}$ の調整範团で本粒剂の $1.5 \sim 2.0 \mathrm{~kg} / 10 \mathrm{a}$ が散布 でき，とくに支障はなかった。

\section{簡便散布法について}

本粒剂が水面に浮上し，有効成分を水面に効率よく展 開させる性質を利用した薬剂の簡便散布法についてその 概要を紹介する.

\section{1. 額縁散布法}

水田の畦畔沿いから 2 4 m に水田全面分の薬量を散 布し，中央まで薬剤を展開させることを考光，シクロプ

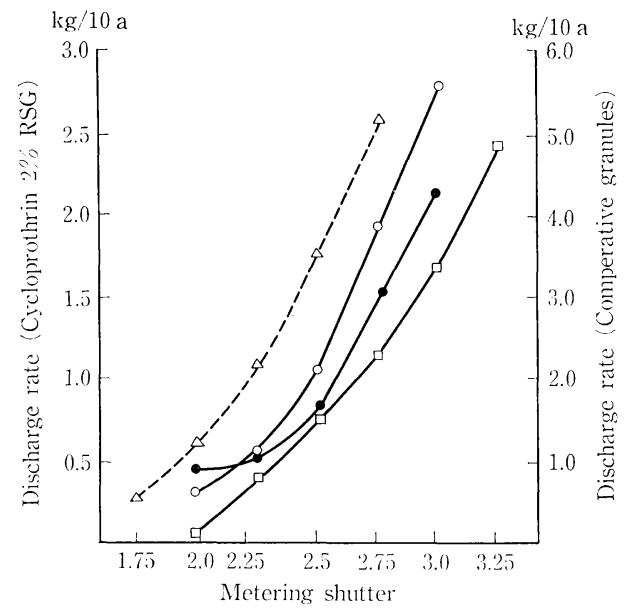

Fig. 8 Discharge rate of granules from hand granule applicator.

Applicator; Minoru banno granule applicator B-D. Swath width, $4 \mathrm{~m}$; Application speed, $25 \mathrm{~m} / \mathrm{min}$. Application time, $10 \mathrm{~min}$.

O. Cycloprothrine 2\% RSG; $\square$, MPP.BPMC G; $\triangle$, Diazinon $5 \%$ G; $\bullet$, MCPB.simetryn-thiobencarb G. 


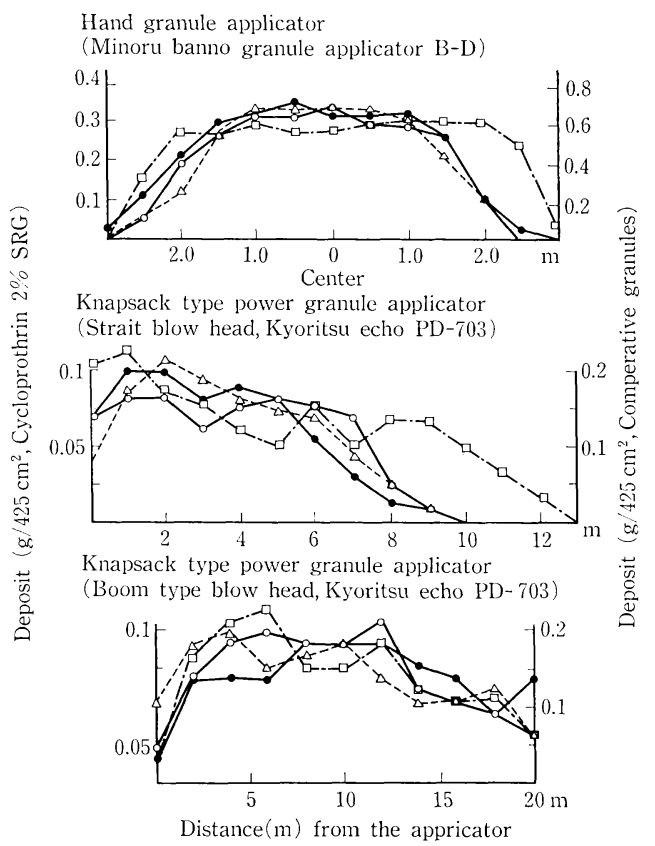

Fig. 9 Deposit distribution of granules by using applicator.

O, Cycloprothrine 2\% RSG $(1.5 \mathrm{~kg} / 10 \mathrm{a})$; MPP.BPMC G(3 kg/10 a); $\triangle$, Diazinon $5 \% \mathrm{G}(3$ $\mathrm{kg} / 10 \mathrm{a}) ; \square$, MCPB.Simetryn. Thiobencarb G(3 $\mathrm{kg} / 10 \mathrm{a})$.

ロトリン水面浮上性粒剂で試験した結果，位置による活 性成分の量に多少のむらがあるもののイネミズゾウムシ 成虫に対する殺虫力を示す量のシクロプロトリンは全面 に行き渡り，防除効果も水田全面で十分に認められた。

\section{2. 水溶性フィルムパック製剤の処理}

本粒剤をポリビニルアルコール等の水溶性フィルムで 包装し，これをそのまま水田などに投げ込む方法であ る.散布機を使用しないで畦畔から簡便に薬剤処理がで きること，薬剂を直接手等に触れなくてすみ衛生的であ ること等の長所があり，この方法が成功すれば画期的で あると思われる.

シクロプロトリンの本粒剤 $100 \mathrm{~g}$ を厚さ $0.04 \mathrm{~mm}$ のポ リビニルアルコールフィルム袋に入れ，水中に投げ込む と数分でフィルムが溶けて粒の浮上が始まり，4時間程 度で浮上は注ぼ完了し，有効成分が順調に水面に展開し た.さらに水面展開力の高い粒剂の検討，単位面積当り の投入量など今後の研究に期待したい.

そのほかにも水口施用法等水面展開性を活かした簡便 散布法が考えられるが，実用化するためにはいずれの方
法も水田条件を十分に考虑した研究が必要である。

\section{おおりに}

有効成分をいかに効率よく防除効果に結びつけた水面 施用粒剂を作るかは製剤研究者にとって長年の命題であ った.

そのために粒を水面に浮遊させて粒剂の土壤吸着を少 なくした浮遊性粒剤が長年研究されてきたが，実用的な 水準まで到達したものはほとんどなかった．著者らは目 的のまったく異なった粒状物の製造研究をしているら ち，完成したその粒状物が水中で一旦沈んでやがて浮上 するといら興味のある挙動を示すことを発見し，このよ らな挙動を示す水面施用粒剤の基剤を工業的に製造する 方法を確立した．これと昔から使用されていた水面展開 性油状製剤を結び付けて活性成分が水面に展開する水面 浮上性粒状製剂を作成し，効力的にも十分であることを 確認し，完成に至った. これは長年の命題の解決策とし てその方向性を示すものと考えてよいのではないかと思 う. 今後,さらにこの研究を進め, 簡便な水面施用法や 殺虫剂以外の分野への適用などへ展開をはかっていきた いと考えている.

最後に, 栄えある日本農薬学会賞業績（技術）賞受賞 にあたり，ご推薦およびご選考いただいた諸先生方，ま た，本粒剤の開発にあたって，多大なご指導をいただい た「1984 年度農薬資材費低減化技術確立事業」の鈴木照 麿委員長を初めとする技術確立委員会のメンバー諸氏, 日本植物防疫協会ならびに国公立試験研究機関, 製造に あたってご協力をいただいたクニミネ工業株式会社, 常 にご支援をいただいた日本化薬(怢)上尾研究所の関係研究 室の多くの方々に心から感謝するとともに，栄誉をとも に分かち合いたいと思います。

\section{引用文 献}

1）小沢政彦(三共)：特公昭 44-8600(1969)

2) 岡本幸和(住友化学)：特公昭 45-9560(1970)

3）岩根吉孝・吉本昌弘・松本照義・田中信彦・佐川隆 夫・富堅邦彦(中外製薬)：特公昭 47-1240(1972)

4) 片岡安克・田辺洋介 (大日本インキ化学): 特公昭 47-27930(1972)

5）川崎政志・武島正巳(日本農薬)：特公昭 49-1180 (1974)

6) 永田健二 - 辻垣内親 (神東塗料)：特公昭 48-1181 (1973)

7）川崎政志・武島正巳 - 中村 弘(日本農薬)：特公 昭 48-1182(1973)

8) 加藤陸郎 - 藤本昌平 - 岩井雅樹 (日本特殊農薬)： 
特公昭 48-15613(1973)

9）村山 普 - 京極和旭 - 林 晃史 - 佐山義克 (大正製

薬)： 特公昭 49-24222(1974)

10）山本隆司 · 服部隆宏 · 山根藤寿 - 三村德衛 - 深田 稔(日本農薬)：特公昭 58-26882(1983)

11) 山本隆司 · 山根藤寿 · 三村德衛 - 深田 稔(日本農 薬)：特開昭 55-139308(1980)

12）兽崎光敏・藤井康夫 (三笠化学)： 特開昭58-65203 (1983)

13）関口幹夫 · 高橋 巌・堺 信一 - 桝井昭夫 - 小島 敏克 (日本化薬)：特公昭 63-30281(1988)

14) 平野千里：応動昆 11，34(1967)

15) 湖山利篤：応動昆 12,230(1969)

16）堺 信一：昭和 59 年度農薬資材費低減化技術確 立事業報告, 日本植物防疫協会編, pp. 20-33, 1984

17）渡部哲夫 - 桝井昭夫 - 桐原重樹：日本応用動物昆 虫学会第 33 回大会講演要旨集, p. 206, 1989

18）小嶋昭雄 - 山代千加子 - 有坂通展 - 渡部哲夫 - 丹 羽吉和：北陸病虫研報 38, 114(1990)

19）清水喜一 - 榎本祐司：日本応用動物昆虫学会 第 34 回大会講演要旨集, p. 206, 1990 